\title{
Is the Surgical Approach Affecting the Late Outcome Results of Open Reduction and Internal Fixation of Femoral Head Fractures?
}

\author{
Mohamed.M.Elzohairy and Adel. M. Salama \\ Faculty of medicine, Zagazig University Egypt, Department of \\ Orthopedics
}

Received date: 10 November 2013; Accepted date: 23 January 2014; published date: 16 May 2014

Academic Editor: Serdar Toker

Copyright (C2014. Mohamed.M.Elzohairy and Adel.M. Salama.Distributed under Creative Commons CC-BY 3.0

\begin{abstract}
Femoral head fracture is a relatively rare injury which often associates with a poor functional outcome. The surgical approaches for femoral head fracture are a controversial subject in many study reports. Patients and Methods Nineteen patients suffering from femoral head fracture-dislocation of the hip were admitted to Zagazig university hospital. The fractures were classified according to the Pipkin classification and all of them were classified as Pipkin Type-II. All fractures were associated with a posterior dislocation Thompson \&Epstein type V. The anterior approach (Smith-Petersen) was used in eight cases, the lateral transgluteal or Thomine modification of Hardinge approach was used in six cases and the posterior (Kocher-Langenbeck) was used in five cases. The results, evaluations were based on clinical and radiographic evaluation, with Thompson \&Epstein score and clinical evaluation, with the Merle d'Aubigné \&Postel score. Results After Followup ranging from 2 to 5 years for all patients (range24-60months, main was 34 months), the overall outcome was excellent at $40 \%$, good at $10 \%$, fair at $32 \%$, and poor in $18 \%$. Avascular necrosis was seen in four cases, three of them were with the posterior approach (one case from the three cases done through a posterior approach suffered from hip sublaxation combined with avascular necrosis), and one case was with the anterior approach. Heterotrophic ossification (Brooker, type I) was seen in one case with the anterior approach. Conclusion The lateral transgluteal or Thomine modification of the Hardinge approach giving promising long-term functional results and lower incidence of major complication rates.
\end{abstract}

Keywords: femoral, head, fracture, approach.

Cite this Article as: Mohamed.M.Elzohairy and Adel. M. Salama (2014), "Is the Surgical Approach Affecting the Late Outcome Results of Open Reduction and Internal Fixation of Femoral Head Fractures?" JMED Research, Vol. 2014 (2014), Article ID 399024, DOI: 10.5171/2014.399024 


\section{Introduction}

One of the factors affecting the outcome is surgical exposure utilized for the surgical treatment of femoral head fractures (18). The matter of which operative approach should be utilized for the surgical treatment of femoral head fractures remains controversial, $(4,18)$. Older publications had advocated the use of posterior Kocher-Langenbeck approach and strongly advised against an anterior one, supposing that the latter would damage any residual blood supply to the femoral head, $(4,5,6)$. Nevertheless, anatomical studies have shown that the main source of femoral head vascular supply is the medial femoral circumflex artery (MFCA), and particularly its deepest branch, while the lateral femoral circumflex artery contributes a little to it, $(10,20,25)$. Subsequent studies implemented the anterior Smith-Petersen approach with successful results, accentuating that it offers easy access to and fixation of the fractured head, $(13,15,22)$. Recently, the so-called trochanteric-flip osteotomy exposure with surgical hip dislocation has emerged in the literature as an appropriate approach for these injuries, $(8,9,10,11$, 21).

\section{The Aim of this Study}

The Aim of this prospective clinical study was to evaluate the results of nineteen patients suffering from femoral head fracture-dislocation of the hip managed by different surgical approaches, and comparing our results with the other studies in the literatures as regards the advantages and disadvantages of each approach and its effect on late outcome. All the patients gave informed consent prior to being included in this study.

\section{Patients and Methods}

From July 2005 through October 2011, nineteen patients suffering from femoral head posterior fracture-dislocation of the hip were admitted to Zagazig university hospital. They were 12 males and 7 females, 11 of them were right hip joint and 8 were left hip joint. The dislocation was type $\mathrm{V}$ posterior dislocation according to Thompson and Epstein classification (23). The fractures were classified according to the Pipkin (19) classification, and all of them were classified as Pipkin Type-II. All the fractures were associated with posterior dislocation. The average age at the time of injury was 32 years (ranged from 24 to 45 years). All patients were injured in car accidents. The anterior approach (Smith-Petersen) was used in eight cases, the lateral transgluteal or Thomine modification of Hardinge approach was used in six cases, and the posterior (Kocher-Langenbeck) was used in five cases. After open reduction, the fractures had been internally fixed with screws, (either Herbert or navicular $4 \mathrm{~mm}$ screws). Preoperatively, intravenous antibiotics are given to remove the drain (Cefotaxime $1 \mathrm{~g}$, two times a day, then followed by ciprofloxacin orally $750 \mathrm{mg}$ two times a day till the sutures got removed). Patients are discharged from the hospital after safe mobilization and non-draining wounds. Suture removed after 14 days. During the first 8 weeks, only toe touch weight bearing and no active muscle exercises are allowed. Radiographs are taken immediately postoperative and at 8 and 12 weeks as well as $6,12,24$ months, and up to 5 years after surgery in two patients. When the radiographs at 8 weeks showed fracture healing, progressive weight-bearing and active exercises for strengthening the abductor muscles started. Patients are recommended to perform low impact training such as swimming or cycling. All patients used two crutches for six months. The results, evaluations were based on clinical outcomes and radiographic evaluations, and on the functional outcomes with Thompson VP, Epstein HC (23) score, and Merle d'Aubigné R, Postel M (17). Microsoft Excel 2010 for windows (Microsoft Corp, Redwood, Washington) was used for statistical analysis of the recording, extracting data and comparing it with the data from the literatures.

\section{Results}

All the fractures were united within 8 weeks, the functional outcome results were evaluated according to the two commonly 
used evaluations: the Thompson \& Epstein score and Merle d'Aubigné \& Postel score. The Merle d'Aubigné \& Postel score are based equally on pain, mobility and walking ability on a scale of 0-6 points each for a maximum of 18 points. After Follow-up ranging from 2 to 5 years for all patients (range 24-60 months, main was 34 months), the overall outcome was excellent at $40 \%$, good at $10 \%$, fair at $32 \%$, and poor at $18 \%$. Avascular necrosis was seen in four cases, three of them were with the posterior approach and the other remaining case was approached via the anterior approach, (one case from the three cases done through posterior approach suffered from hip sublaxation and osteoarthrosis combined with avascular necrosis which was converted to cementless total hip replacement and the other remaining cases suffered from avascular necrosis refused further treatment. Heterotrophic ossification was classified according to Brooker classification, Brooker et al (1973).

(Brooker, type I) heterotrophic ossification was seen in two cases, one case with the anterior approach and the other case with the posterior approach. For posttraumatic arthrosis, we followed the classification of Thompson \& Epstein, the osteoarthrosis occurred in three cases, one with anterior approach and two with the posterior approach. No infection was recorded. There were three posttraumatic (presurgical) sciatic nerve injuries, all of them completely recovered within six months. There were no postoperative surgical nerve injuries. The Thompson and Epstein score consists of the determination of clinical and radiographic scores, each of which is given a rating of excellent, good, fair, or poor. The worst of these (usually the radiographic one) determines the final score. Although some reports classify a hip prosthesis as a good result, we feel that with the exception of a Pipkin III fracture in an elderly patient, the treatment goal in Pipkin fractures should be to preserve the joint. In our patient analysis, therefore, we determined an arthroplasty as a poor outcome, whether it was done primarily or as a salvage option. A similar scenario was also used for a hip arthrodesis. (Tables 1, 2) and (Figures from 1-14).

Table 1: Results according to Merle d 'Aubigné \&Postel score and Thompson \&Epstein score

\begin{tabular}{|c|c|}
\hline Excellent & $40 \%$ \\
\hline good & $10 \%$ \\
\hline fair & $32 \%$ \\
\hline Poor & $18 \%$ \\
\hline
\end{tabular}


Table 2: Complications according to different surgical approaches.

\begin{tabular}{|l|c|c|c|}
\hline \multicolumn{1}{|c|}{ The approach } & Anterior & Posterior & Lateral \\
\hline Avascular necrosis & $\mathbf{1}$ & $\mathbf{3}$ & $\mathbf{0}$ \\
\hline Hip sublaxation & $\mathbf{0}$ & $\mathbf{1}$ & $\mathbf{0}$ \\
\hline Heterotropic ossification & $\mathbf{1}$ & $\mathbf{1}$ & $\mathbf{0}$ \\
\hline Osteoarthrosis & $\mathbf{1}$ & $\mathbf{2}$ & $\mathbf{0}$ \\
\hline
\end{tabular}

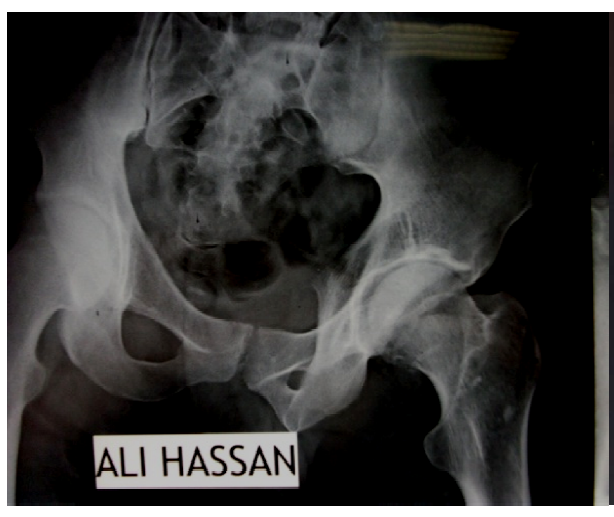

Figure1

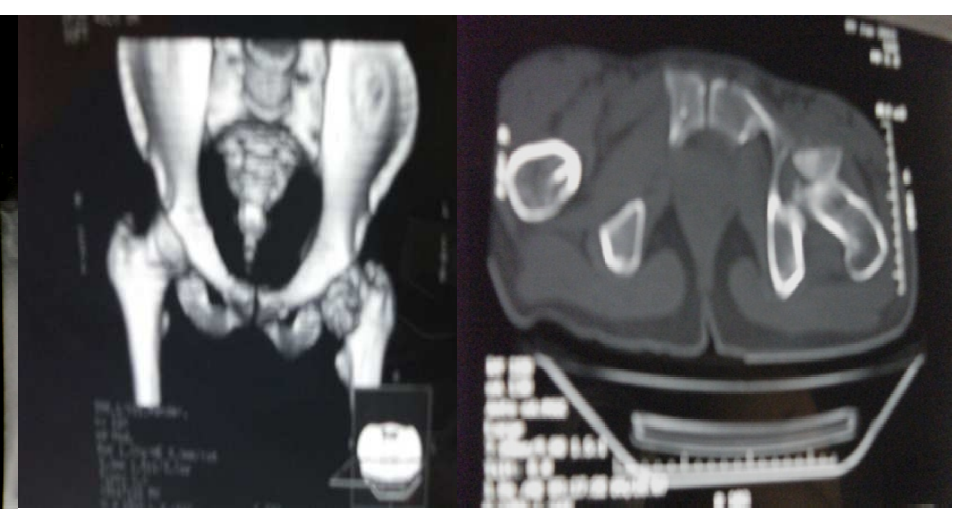

Figure2

Figure3
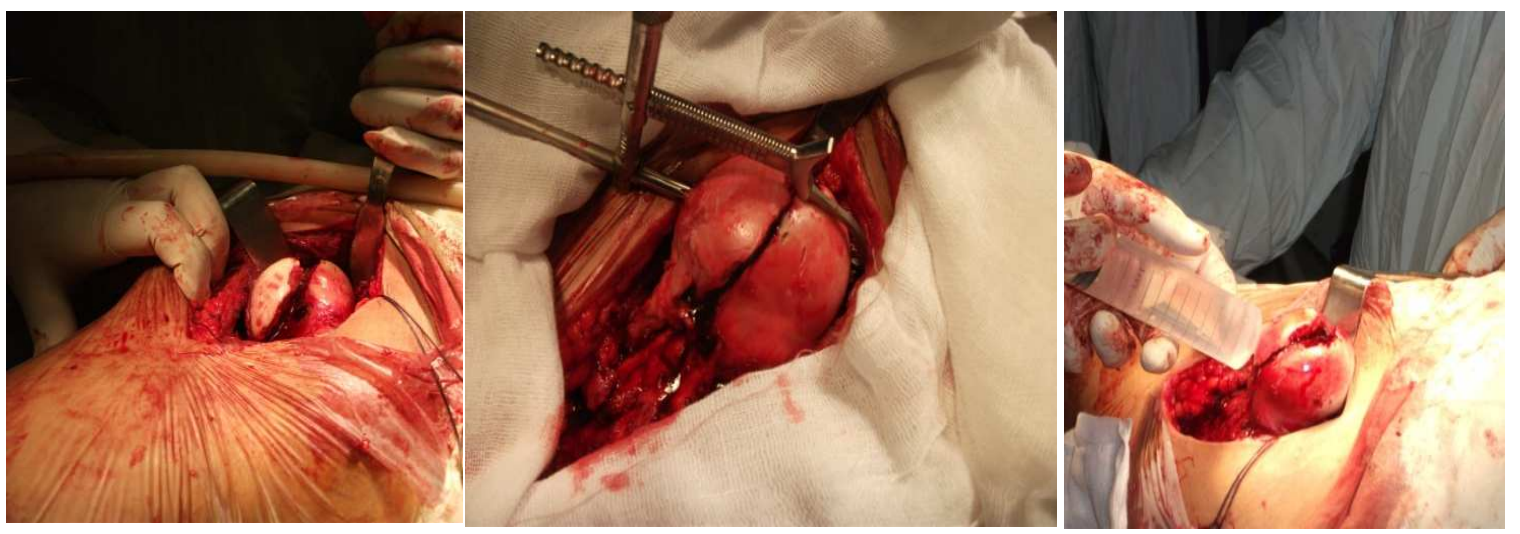

Figure 4

Figure 5

Figure 6 


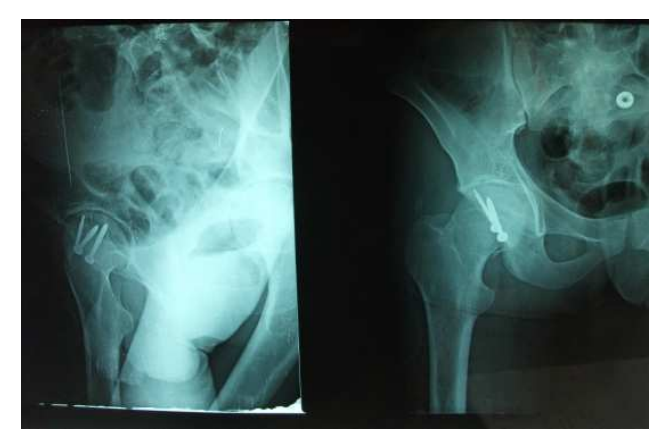

Figure 7

Case (1): Figure (1) X ray showed the double shadows of the fracture femoral head, Figures (2, 3 ) shows the CT of the fractures, Figures $(4,5,6)$ through lateral transgluteal approach fixation with one Herbert screw and two navicular cancellous screws $4 \mathrm{~mm}$, Figure (7) the X ray after three years follow up no heterotropic ossification, avascular necrosis and posttraumatic arthrosis with excellent outcome

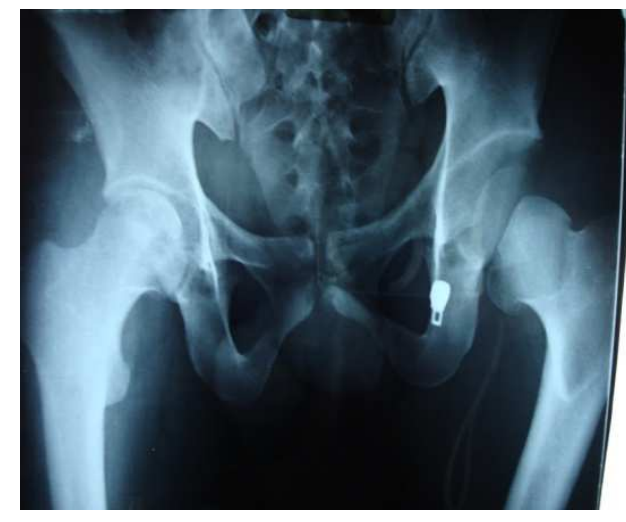

Figure 8

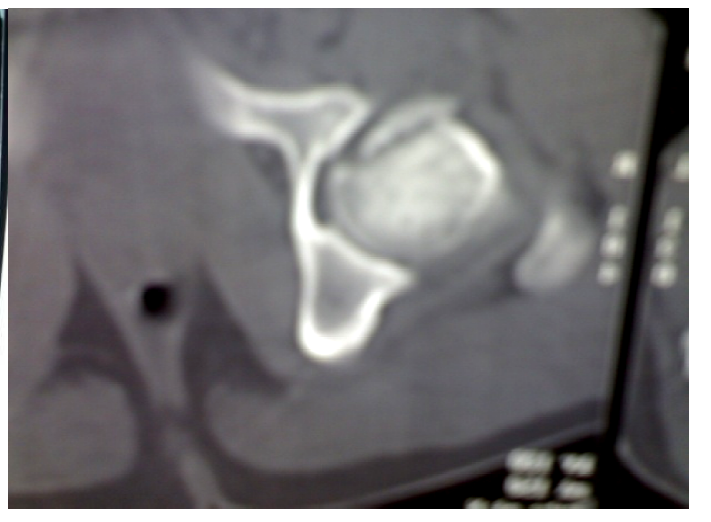

Figure 9

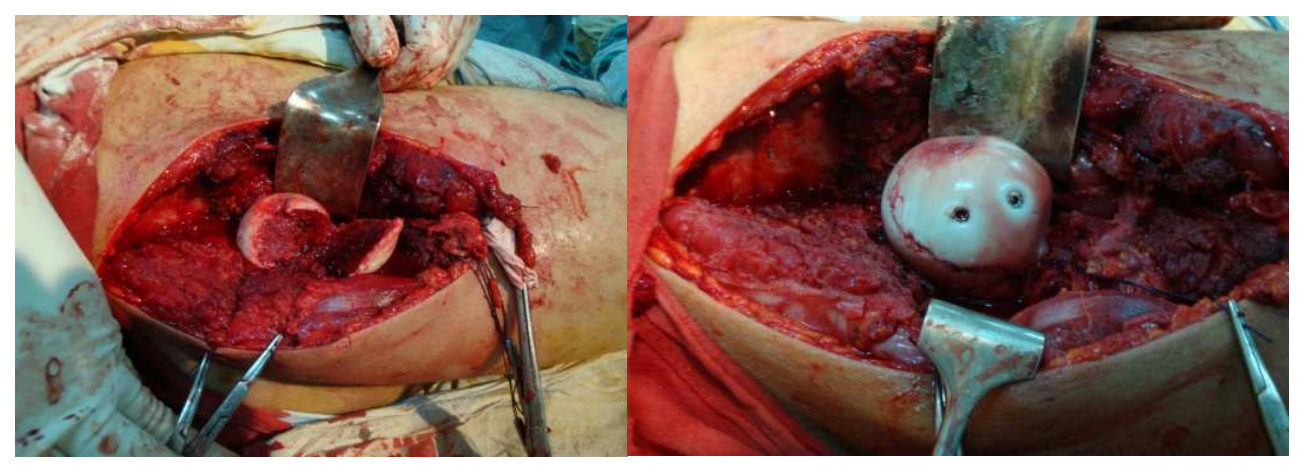

Figure 10

Figure 11 


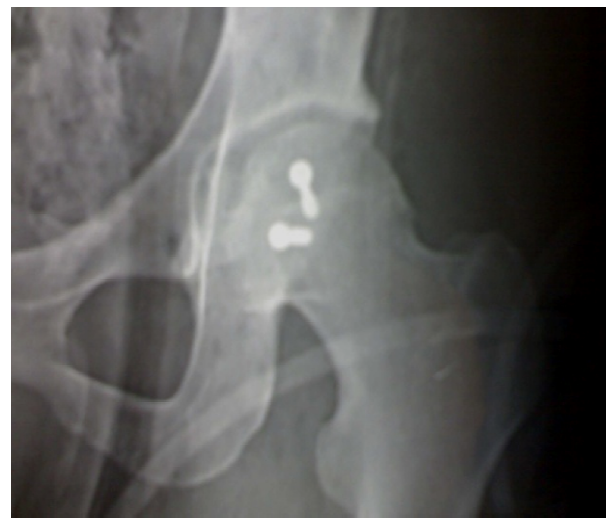

Figure 12

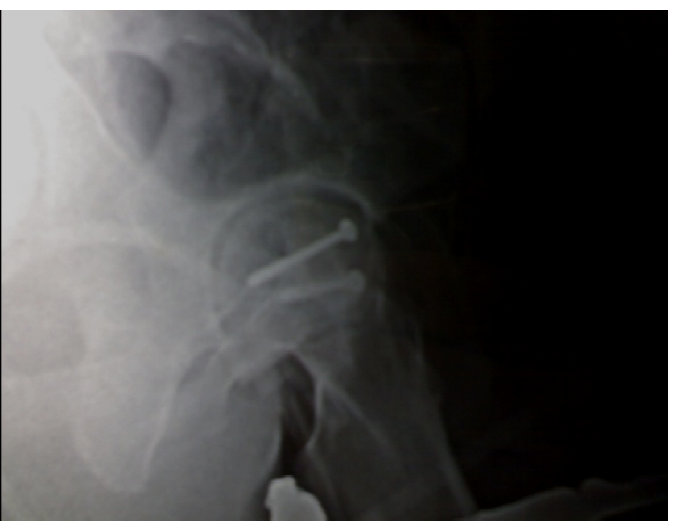

Figure 13

Case (2): Figure (8,) X ray showed the fracture femoral head, Figures (9) shows the CT of the fractures, Figures $(10,11)$ through anterior approach fixation with two navicular cancellous screws $4 \mathrm{~mm}$, Figure $(12,13)$ the X ray after three year fellow up no heterotropic ossification, avascular necrosis and posttraumatic arthrosis with excellent outcome.

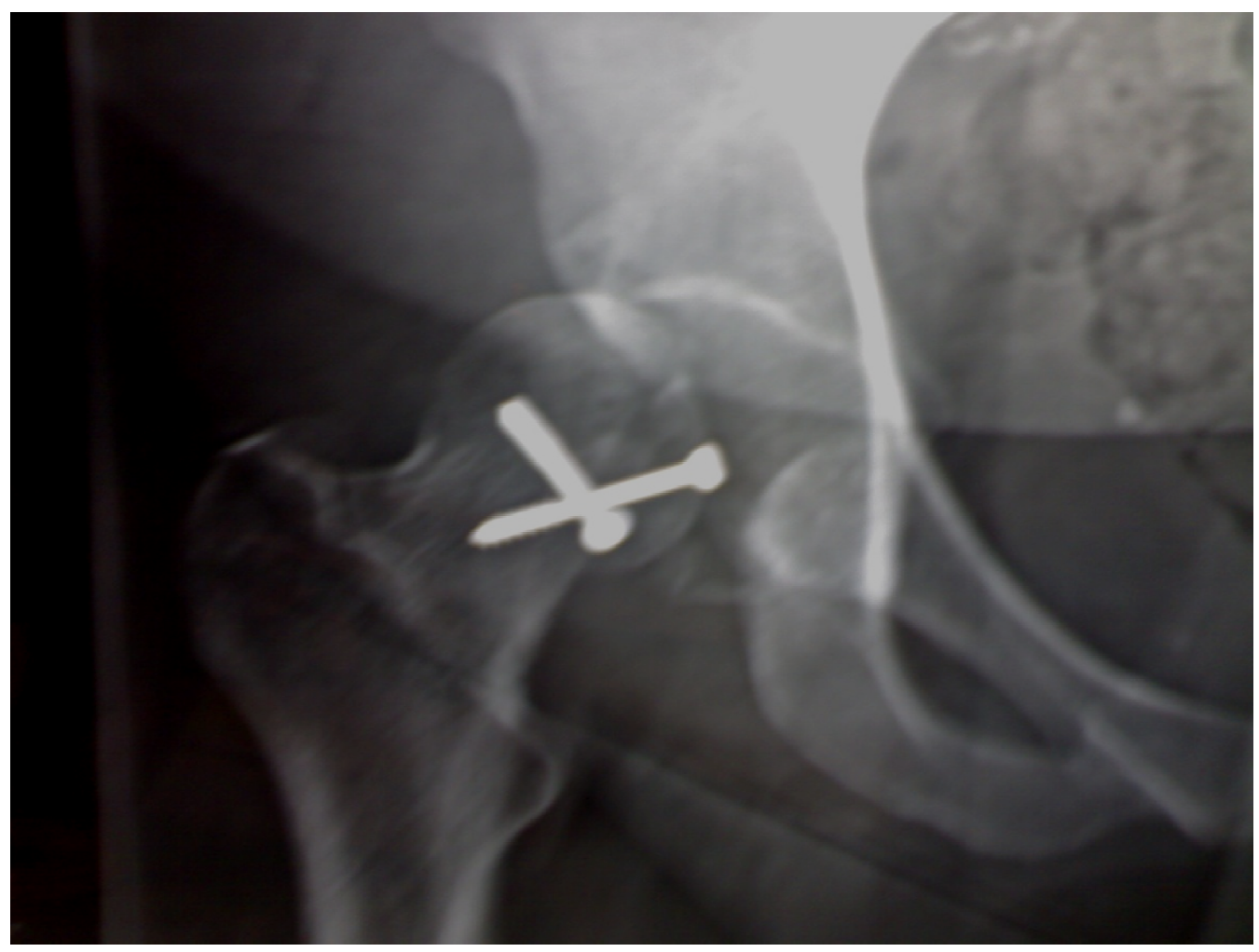

Case (3): The X-ray shows avascular necrosis and hip sublaxation after the posterior approach used for ORIF of femoral head fracture.

In our study, the incidence of AVN by using the anterior approach was $12.5 \%$, in comparison to the incidence of AVN by using the posterior approach which was $60 \%$, and the incidence of AVN by using the lateral approach which was $0 \%$. The incidence of arthritis by using the anterior approach was $12.5 \%$, in comparison to the incidence of arthritis by using the posterior approach which was $40 \%$, and the 
incidence of arthritis by using the lateral approach which was $0 \%$. The incidence of HO by using the anterior approach was $12.5 \%$ in our study, in comparison to the incidence of $\mathrm{HO}$ by using the posterior approach which was $20 \%$ in our study, and the incidence of $\mathrm{HO}$ by using the lateral approach was $0 \%$ in our study.

\section{Discussion}

There are many different surgical approaches with different advantages and disadvantages. Those approaches, including posterior (Kocher-Langenbeck), anterior (Smith-Petersen), anterolateral (Watson-Jones), and medial (Ludloff), trochanteric flip osteotomy and lateral transgluteal or Thomine modification of Hardinge approach, each one has its merits and demerits, as regards the complications as heterotropic ossification, avascular necrosis, posttraumatic arthrosis and the functional outcome, $(2,3,6,7,12,14,22)$. A recent comparative study between anterior and posterior approaches for Pipkin I and II fractures showed that the use of the anterior approach gave less blood loss, shorter operating times, and better visualization. However, more heterotropic ossification after the anterior approach was indeed seen. Another common criticism of an anterior-based approach is that it will damage most, if not all, remaining blood supply to the femoral head that was dislocated posteriorly. However, this theory has not been strongly supported in recent literature, which shows that there is little-to-no interference with the blood supply to the femoral head via this approach. Epstein et al (5), Swiontkowski et al (22) and Giannoudis et al (11), in their studies to detect the safe surgical approach, they collected data from 11 articles relating the preferred surgical exposure to the complications encountered, mainly those of avascular necrosis and heterotopic ossification. They had to state that the choice of approach is frequently dictated by the fracture pattern and the overall injury severity characteristics. Regarding major late complications' odds, ratio analysis demonstrated a trend to a higher incidence of HO (all Brooker stages) after a trochanteric-flip osteotomy exposure relative to the posterior one. Furthermore, an over twofold trend of the likelihood of AVN existed when a posterior rather than an anterior or trochanteric-flip osteotomy approach was performed, whereas for post-traumatic arthritis, a higher incidence was found in case of an anterior or posterior approach respectively versus a trochanteric-flip osteotomy. This finding, however, may be partially due to the shorter mean follow-up time (37.2 months) for the cases treated with the trochanteric-flip osteotomy, compared with those of anterior (44.27 months) and posterior (44.8 months), and due to the fact that the greater number of cases with arthritis was extracted from one study. Additional explanations for this result may lie on the view of the proponents of the trochanteric-flip osteotomy, who state that this approach allows excellent inspection of the joint for removing loose fragments and anatomically reducing and securely fixing the head and/or acetabulum fracture. Higher rates of HO were observed with this exposure (including all Brooker stages), but there was no compromise to the final functional outcome, and they concluded that the incidence of avascular necrosis of the femoral head after femoral head fracture was $11.8 \%$. They also indicated that in patients treated surgically, the likelihood of AVN was 3.67 and 2.24 times higher in the posterior than in the anterior or trochanteric flip osteotomy approach respectively. In another series by Uzel et al (26), they found that there is a high risk of femoral head fractures in Pipkin II irreducible type dislocations during reduction, and that the transgluteal approach with the patient in the lateral decubitus position provides direct anterior-inferior-medial and dorsal access to the fracture site because of musculocapsular lesions caused by the dislocation, and they preferred the lateral transgluteal approach compared with the other in the literature as regarding the advantages and the disadvantages. As regards our series of 19 patients suffering from posterior hip dislocations with femoral head fractures managed with different surgical approaches, comparing our study results with the results of other studies, we had made a statistical analysis, and we have found that, the incidence of AVN using the anterior approach was $12.5 \%$ in our study compared to $5.3 \%$ of 
the other studies, the incidence of AVN using the posterior approach was $60 \%$ in our study compared to $16.9 \%$ of the other studies, and the incidence of AVN using the lateral approach was $0 \%$ in our study compared to $11.1 \%$ of the other studies. The incidence of arthritis using the anterior approach was $12.5 \%$ in our study compared to $21 \%$ in the other studies, the incidence of arthritis using the posterior approach was $40 \%$ in our study compared to $29.2 \%$ of the other studies, and the incidence of arthritis using the lateral approach was $0 \%$ in our study compared to $0 \%$ of the other studies. The incidence of HO using the anterior approach was $12.5 \%$ in our study compared to $44.7 \%$ of the other studies, the incidence of $\mathrm{HO}$ using the posterior approach was $20 \%$ in our study compared to $32.3 \%$ of the other studies, and the incidence of HO using the lateral approach was $0 \%$ in our study compared to $0 \%$ of the other studies, (figures 15, 16, 17). Our study could be added to the other database in literature, to give an overall concept and idea about the preferred safe surgical approach. The role of hip arthroscopy, whatever the approach used, is a new raising concept in the literatures. There is a recent concept evolving about the role of the hip arthroscopy during the surgery for open reduction and internal fixation of femoral head fractures, (figures 15, 16, 17). Matsuda (16) had one case report managed by hip arthroscopy, and there is also another series of four cases managed by hip arthroscopy by Tonetti et al (24); both of them had promising results. So, this will encourage us to use this technique, and fully investigate this method as a minimally invasive hip surgery for open reduction and internal fixation of femoral head fractures in the future.

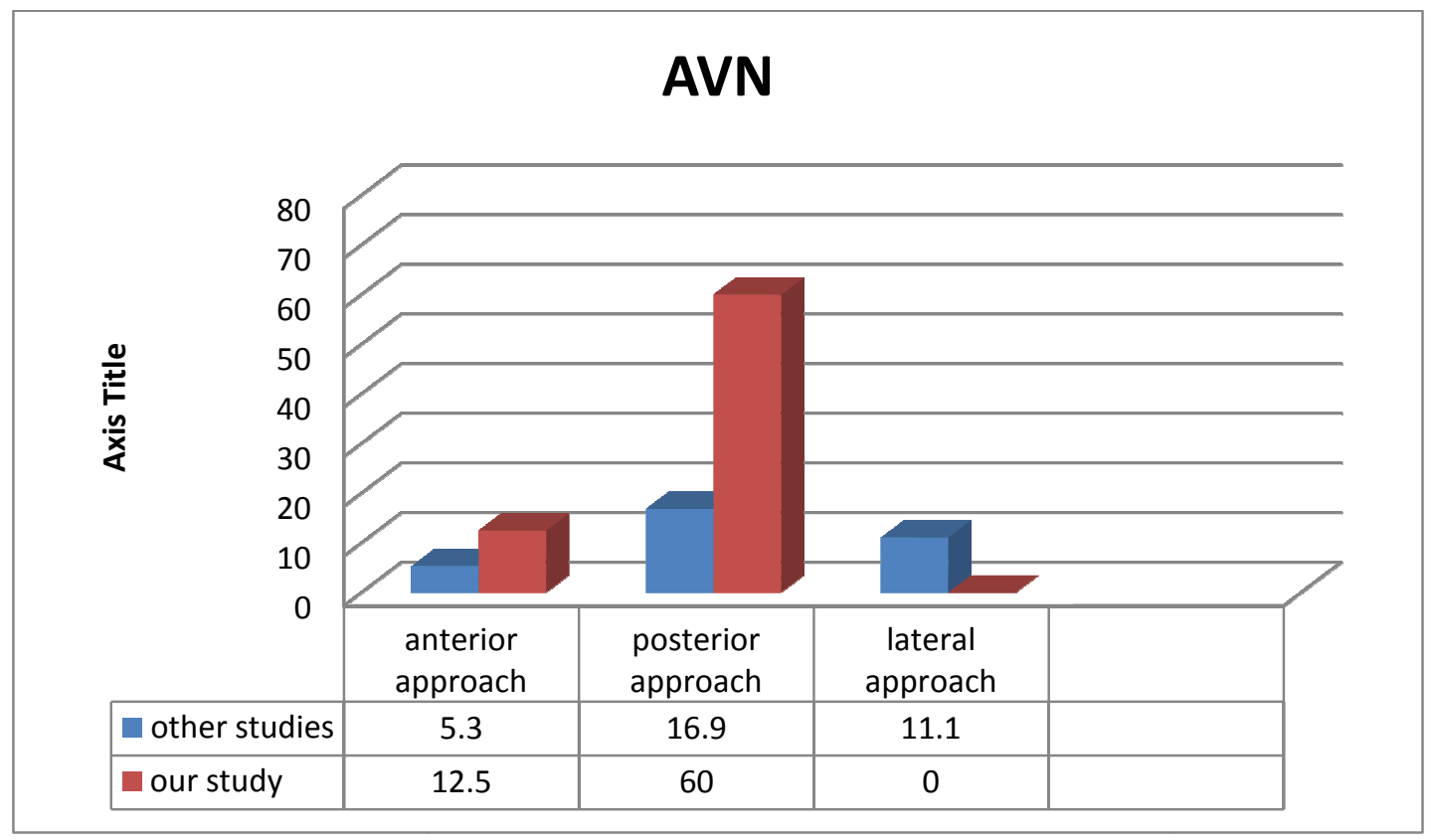

Figure 15: this figure showed that incidence AVN in our studies compared to the other studies. 


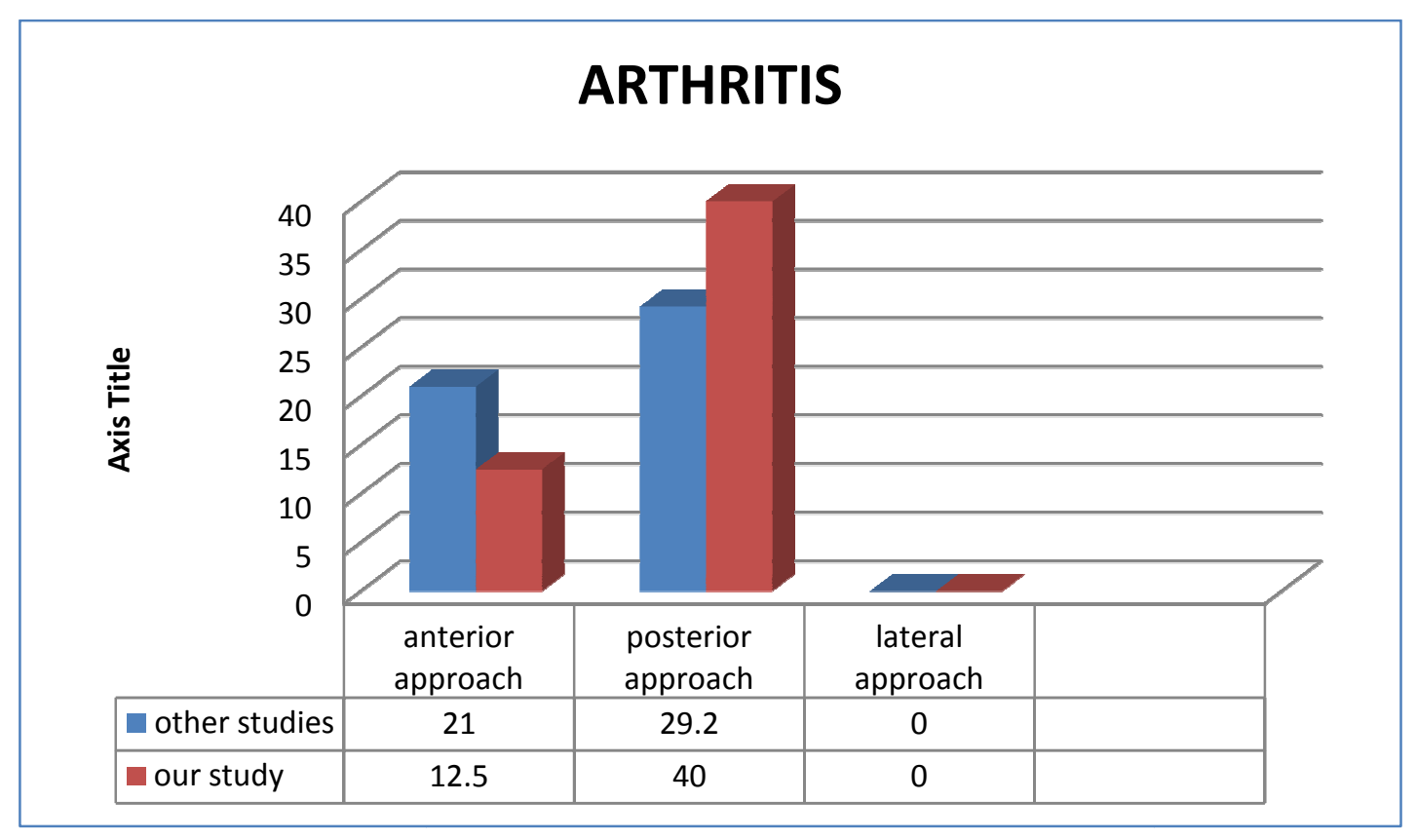

Figure 16: this figure showed that incidence ARTHRITIS in our studies compared to the other studies.

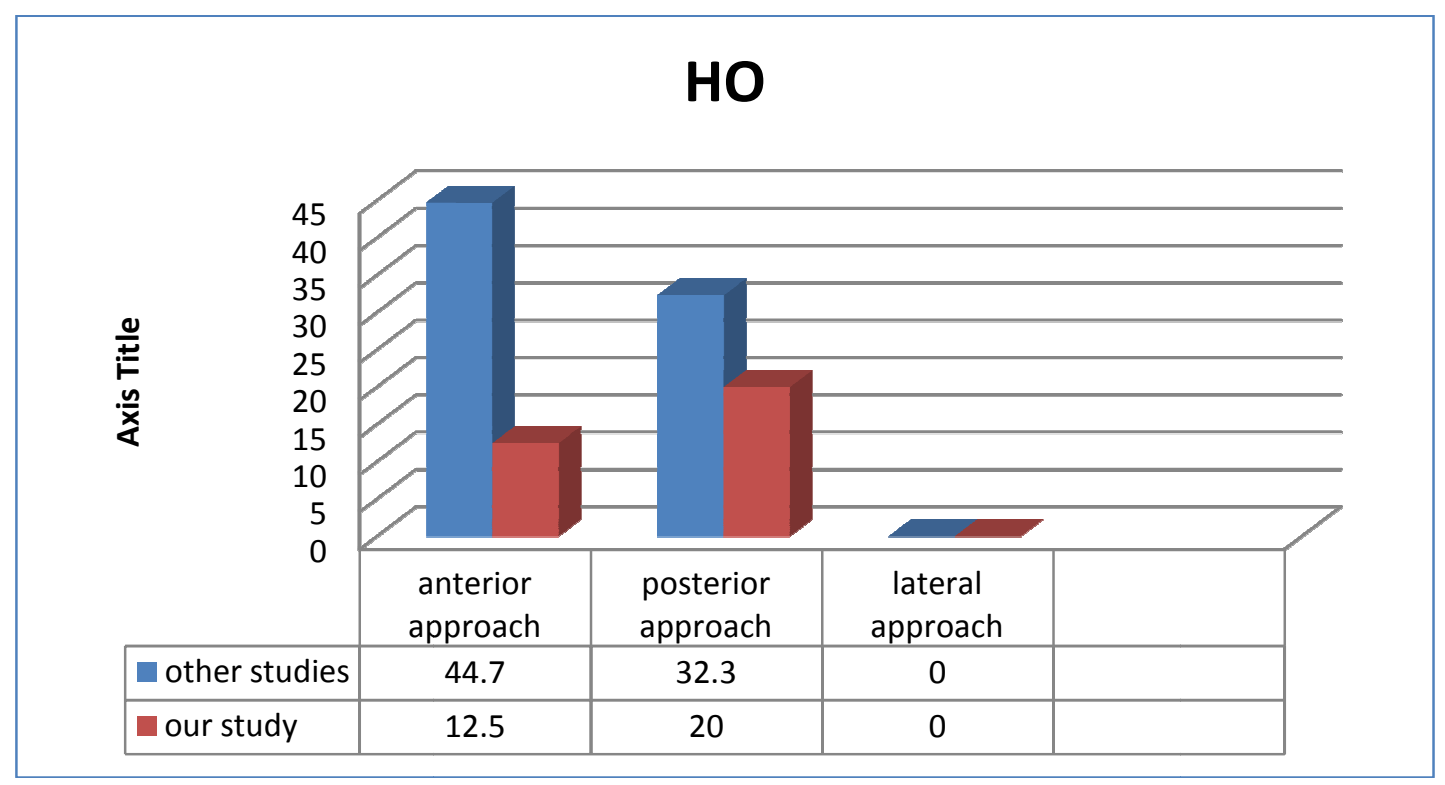

Figure 17: This figure showed that incidence HO in our studies compared to the other studie 
Table 3: Advantages and disadvantages of the different surgical approaches proposed for the treatment of femoral head fracture-dislocations.

\begin{tabular}{|c|c|c|c|c|}
\hline & Advantage 1 & Advantage 2 & Disadvantage 1 & Disadvantage 2 \\
\hline $\begin{array}{l}\text { Lateral approach } \\
\text { with } \\
\text { trochanterotomy }\end{array}$ & $\begin{array}{l}\text { Good access to } \\
\text { the anterior and } \\
\text { posterior part of } \\
\text { the joint }\end{array}$ & & $\begin{array}{l}\text { Necrosis due to } \\
\text { possible injury } \\
\text { to the circumflex } \\
\text { artery during } \\
\text { trochanterotomy }\end{array}$ & $\begin{array}{l}\text { Pseudarthrosis } \\
\text { of the } \\
\text { trochanteric } \\
\text { region }\end{array}$ \\
\hline $\begin{array}{l}\text { Posterior } \\
\text { approach }\end{array}$ & $\begin{array}{l}\text { Good access to } \\
\text { the posterior } \\
\text { dislocation and } \\
\text { the posterior } \\
\text { wall of the } \\
\text { acetabulum }\end{array}$ & $\begin{array}{lr}\text { Good for } & \text { the } \\
\text { treatment } & \text { of } \\
\text { Pipkin } & \text { IV } \\
\text { fractures } & \end{array}$ & $\begin{array}{ll}\text { Difficult } & \text { to } \\
\text { control } & \\
\text { reduction } & \end{array}$ & $\begin{array}{l}\text { No direct } \\
\text { fixation of the } \\
\text { femoral head }\end{array}$ \\
\hline $\begin{array}{l}\text { Watson-Jones } \\
\text { approach }\end{array}$ & No MCA injury & $\begin{array}{l}\text { Visual control of } \\
\text { reduction of } \\
\text { dislocation and } \\
\text { direct fixation of } \\
\text { the fragment } \\
\text { after dislocation } \\
\text { of the hip }\end{array}$ & $\begin{array}{l}\text { Possible } \\
\text { superior gluteal } \\
\text { nerve injury }\end{array}$ & $\begin{array}{l}\text { No dorsal access } \\
\text { in the presence } \\
\text { of an irreducible } \\
\text { dislocation, to } \\
\text { reduce the hip } \\
\text { and free any } \\
\text { incarceration }\end{array}$ \\
\hline $\begin{array}{l}\text { Smith-Petersen } \\
\text { approach }\end{array}$ & No MCA injury & $\begin{array}{l}\text { Visual control of } \\
\text { reduction of the } \\
\text { dislocation and } \\
\text { direct fixation of } \\
\text { the fragment } \\
\text { after dislocation } \\
\text { of the hip }\end{array}$ & $\begin{array}{l}\text { Can only be } \\
\text { performed in the } \\
\text { decubitus dorsal } \\
\text { position }\end{array}$ & $\begin{array}{l}\text { No dorsal access } \\
\text { in the presence } \\
\text { of an irreducible } \\
\text { dislocation, to } \\
\text { reduce the hip } \\
\text { and free any } \\
\text { incarceration }\end{array}$ \\
\hline $\begin{array}{l}\text { Hardinge or } \\
\text { Thomine type } \\
\text { transgluteal } \\
\text { approach }\end{array}$ & No MCA injury & $\begin{array}{l}\text { Visual control of } \\
\text { reduction of the } \\
\text { dislocation and } \\
\text { direct fixation of } \\
\text { the fragment } \\
\text { after dislocation } \\
\text { of the hip }\end{array}$ & $\begin{array}{l}\text { Performed in } \\
\text { decubitus lateral } \\
\text { position }\end{array}$ & $\begin{array}{lr}\text { Dorsal } & \text { access } \\
\text { possible } & \text { through } \\
\text { soft } & \text { tissue } \\
\text { damage } & \text { caused } \\
\text { by } & \text { the } \\
\text { dislocation }\end{array}$ \\
\hline $\begin{array}{l}\text { Digastric } \\
\text { Trochanterotomy }\end{array}$ & $\begin{array}{l}360 \text { accesses to } \\
\text { the acetabulum } \\
\text { and the femoral } \\
\text { head }\end{array}$ & $\begin{array}{l}\text { Good for the } \\
\text { treatment of } \\
\text { Pipkin type IV } \\
\text { fractures Direct } \\
\text { screw fixation } \\
\text { possible if the } \\
\text { ligament tears } \\
\text { famous are } \\
\text { incised }\end{array}$ & $\begin{array}{l}\text { Trochanteric } \\
\text { osteosyntesis } \\
\text { may fail }\end{array}$ & $\begin{array}{l}\text { Trochanteric } \\
\text { pseudarthrosis } \\
\text { (but less than in } \\
\text { with a classic } \\
\text { trochanterotomy } \\
\text { because the } \\
\text { gluteal medius } \\
\text { and the vastus } \\
\text { lateralis remain } \\
\text { intact }\end{array}$ \\
\hline Ludloff approach & $\begin{array}{l}\text { Anatomical } \\
\text { approach with } \\
\text { no incision of } \\
\text { muscle }\end{array}$ & $\begin{array}{lr}\text { Direct } & \text { screw } \\
\text { fixation, } & \text { the } \\
\text { ligament } & \text { tears } \\
\text { femoris } & \text { is } \\
\text { preserved } & \\
\end{array}$ & $\begin{array}{l}\text { Control limited } \\
\text { to } \quad \text { the } \\
\text { coxofemoral } \\
\text { joint }\end{array}$ & $\begin{array}{l}\text { rarely used, near } \\
\text { to the genital } \\
\text { region }\end{array}$ \\
\hline
\end{tabular}

MCA: Medial circumflex artery 


\section{Conclusion}

In conclusion, based on the data collected from our and the other reviews of literature, the results showed that, neither the trochanteric-flip nor the anterior or the lateral approaches seems to put in more danger the femoral head blood supply compared to the posterior one, with the lateral giving promising long-term functional results and lower incidence of major complication rates. The goals of definitive management are to achieve an anatomically reduced femoral head with a stable hip joint, and remove any interposed bone fragments if present. More studies and experiences will be needed to evaluate the results of hip arthroscopy.

\section{References}

1. Brooker AF, Bowerman JW, Robinson RA, Riley LH. (1973). "Ectopic ossification following total hip replacement," J Bone Joint Surg Am, 1973, 55; 1629 -35.

2. Chiron $\mathrm{P}$, Lafontan V, Reina N. (2013)."Fracture-dislocations of the femoral head," Orthopaedics \& Traumatology: Surgery \& Research, 2013, 99S; S53-S66.

3. Droll P Kurt, Broekhuyse Henry, O'Brien, Peter. (2007). "Fracture of the femoral head." J Am Acad Orthop Surg, 2007, 15; 716-727.

4. Epstein. HC. (1961). "Posterior fracture-dislocations of the hip: comparison of open and closed methods of treatment in certain types." J Bone Joint Surg Am, 1961, 43; 1079-98.

5. Epstein HC, Wiss DA, Cozen L, (1985). "Posterior fracture dislocation of the hip with fractures of the femoral head." Clin Orthop Relat Res, 1985, 201; 9-17.

6. Epstein. H. C, (1974). "Posterior Fracture-Dislocations of the Hip." Longterm Follow-up." J. Bone and Joint Surg, 1974, 56-A; 1103-1127.

7. Epstein. H. C. (1980). Traumatic Dislocation of the Hip. Baltimore, Williams and Wilkins.
8. Ganz R, Gill TJ, Gautier E. (2001). "Surgical dislocation of the adult hip a technique with full access to the femoral head and acetabulum without the risk of avascular necrosis." J Bone Joint Surg Br, 2001, 83 (3); 1119-24.

9. Gardner MJ, Suk M, Pearle A. (2005). "Surgical dislocation of the hip for fractures of the femoral head." J Orthop Trauma, 2005, 19 (5); 334-42.

10. Gautier E, Ganz, K, Krugel N, et al. (2002). "Anatomy of the medial femoral circumflex artery and its surgical implications." J Bone Joint Surg Br, 2000, Jul, 82 (5); 679-83.

11. Giannoudis P.V, Kontakis G, Christoforakis. Z, Akula. M, Tosounidis. T, Koutras. C. (2009). "Management, complications and clinical results of femoral head fractures." Injury, Int. J. Care Injured, 2009, 40; 1245-1251.

12. Henle Philipp, Kloen Peter, Siebenrock A Klaus. (2007). "Femoral head injuries: Which treatment strategy can be recommended?." Injury, Int. J. Care Injured, 2007, 38; 478-488.

13. Kloen PSK, Raaymakers E, Marti RK, Ganz R, (2002). "Femoral head fractures revisited." Eur J Trauma, 2002, 4; 221-33.

14. Kokubo Yasuo • Uchida Kenzo • Takeno Kenichi • Yayama Takafumi • Miyazaki Tsuyoshi • Negoro Kohei • Nakajima Hideaki • Sugita Daisuke • Takeura Naoto • Yoshida A • Baba Hisatoshi, (2002). "Dislocated intraarticular femoral head fracture associated with fracture-dislocation of the hip and acetabulum report: of 12 cases and technical notes on surgical intervention." Eur J Orthop Surg Traumatol July, 2002, DOI 10.1007/s00590-012-1027-7.

15. Marchetti ME, Steinberg GG, Coumas JM, (1996). "Intermediate-term experience of Pipkin fracture-dislocations of the hip." $J$ Orthop Trauma, 1996, 10 (7); 455-61.

16. Matsuda. K. Dean, (2009). "A Rare fracture, an Even Rarer Treatment: The 
Arthroscopic Reduction and Internal Fixation of an Isolated Femoral head fracture." The Journal of Arthroscopic \& Related Surgery, 2009, Volume 25, Issue 4, April, Pages 408-412.

17. Merle d'Aubigné R, Postel, M, (1954). "Functional results of hip arthroplasty with acrylic prosthesis." J Bone Joint Surg Am, 1954, 36:451 -75.

18. ÖZCAN Mert, ÇOPUROĞLU Cem, SARIDOĞAN Kenan, (2011). "Fractures of the femoral head: What are the reasons for poor outcome?." Turkish Journal of Trauma \& Emergency Surgery, Ulus Travma Acil Cerrahi Derg, 2011, 17 (1): 51-56.

19. Pipkin G, (1957). "Treatment of grade IV fracture-dislocation of the hip." J Bone Joint Surg Am, 1957, 39; 1027-1042.

20. Sevitt S, Thompson RG, (1965)."The distribution and anastomoses of arteries supplying the head and neck of the femur." J Bone Joint Surg Br, 1965, 47; 560-73.

21. Solberg BD, Moon CN, Franco DP, (2009)." Use of a trochanteric flip osteotomy improves outcomes in Pipkin IV fractures." Clin Orthop Relat Res, 2009, 467(4);929-33.
22. Swiontkowski MF, Thorpe M, Seiler JG, Hansen ST, (1992). "Operative management of displaced femoral head fractures: casematched comparison of anterior versus posterior approaches for Pipkin I and Pipkin II fractures." J Orthop Trauma, 1992, 66,437442.

23. Thompson VP, Epstein HC, (1951). "Traumatic dislocation of the hip. A survey of two hundred and four cases covering a period of twenty-one years." J Bone Joint Surg Am, 1951, 33:746-78.

24. Tonetti J, Ruatti.S, Lafontan V, Loubignac .F, Chiron P, Sari-Ali. H, Bonnevialle. P, (2010). "Is femoral head fracture-dislocation management improvable: A retrospective study in 110 cases." Orthopaedics \& Traumatology: Surgery \& Research, 2010, 96, 623-631.

25. Trueta J, Harrison MH (1953). "The normal vascular anatomy of the femoral head in adult man." $J$ Bone Joint Surg $B r$, 1953, 35-B (3): 442-61.

26. Uzel. PA, Laflamme. Y. G, Rouvillain. L. J, (2010). "Irreducible Pipkin IIfemoral head fractures: Is transgluteal approach the best strategy?." Orthopaedics \& Traumatology, Surgery \& Research, 2010, 96, 695-701. 